\title{
PENGARUH INTERVENSI TAHU KEDELAI HITAM KAYA SERAT TERHADAP GLUKOSA DARAH DAN INFLAMASI RESPONDEN DIABETES TIPE 2
}

\author{
[Effect of Dietary Fiber Rich-Tofu from Black Soybean on Bloods Glucose and \\ Inflammatory Syndrom of Type 2 Diabetes Mellitus Subjects]
}

\author{
Nela Eska Putri ${ }^{1,3) \star}$, Fransiska R. Zakaria ${ }^{2)}$, Endang Prangdimurti ${ }^{2)}$, dan Nanda Triandita ${ }^{1,3)}$ \\ 1) Program Studi IImu Pangan, Sekolah Pasca Sarjana, Institut Pertanian Bogor, Bogor \\ ${ }^{2)}$ Departemen Ilmu dan Teknologi Pangan, Fakultas Teknologi Pertanian, Institut Pertanian Bogor, Bogor \\ 3) Program Studi Ilmu dan Teknologi Pangan, Fakultas Pertanian, Universitas Garut, Garut
}

Diterima 09 Juni 2016 / Disetujui 09 Agustus 2016

\begin{abstract}
Type 2 diabetes mellitus (T2DM) subjects have a hyperglycemia condition. Hyperglycemia can cause oxidative stress that trigger glucose autooxidation and reactive oxygen species (ROS). ROS also triggers the inflammation and induces the cytokine signalling from cells and body tissues, such as interleukin and prostaglandin enzyme (COX-2). The purpose of this research was to analyze the effect of dietary fiber richtofu from black soybean (DFT) on bloods glucose and inflammations of T2DM patients. Intervention group $(n=9)$ was given 80 grams DFT during 30 days and control group $(n=9)$ was not. Blood collections were conducted before and after intervention by certified nurses for all groups for analysis in the laboratory. Fasting Blood Glucose (FBG) was measured by glucometer, while the plasma was analyzed with ELISA to measure the optical density value of IL-6 and COX-2 enzyme. Consumption of DFT resulted in the decline of the optical density of IL-6 value $(p=0.00)$, but DFT could not reduce the FBG and optical density of COX2 enzyme $(p=0.22$ and $p=0.51)$. Therefore DFT can be considered as an effective food for reduction of T2DM inflammatory.
\end{abstract}

Keywords: black soybean tofu, bloods glucose, inflammations, type 2 DM

\begin{abstract}
ABSTRAK
Penderita diabetes melitus tipe 2 mengalami kondisi hiperglikemik. Hiperglikemik dapat menyebabkan stres oksidatif dan timbulnya reactive oxygen species (ROS). ROS dapat meningkatkan sekresi marker inflamasi seperti senyawa IL-6 dan enzim COX-2 oleh jaringan. Tujuan penelitian ini adalah untuk mengetahui pengaruh intervensi tahu kedelai hitam kaya serat (DFT) terhadap glukosa darah dan status inflamasi penderita diabetes melitus tipe 2. Responden dibagi menjadi 2 kelompok yaitu kelompok perlakuan $(n=9)$ yang diintervensikan $80 \mathrm{~g}$ DFT selama 30 hari dan kelompok kontrol $(n=9)$ yang tidak diberikan DFT. Glukosa darah puasa (GDP) dan parameter inflamasi (IL-6 dan enzim COX-2) dianalisis pada hari ke-0 dan hari ke-30. GDP dianalisis menggunakan glukometer, sedangkan nilai optical density IL-6 dan enzim COX-2 dianalisis dari plasma menggunakan metode ELISA. Hasil penelitian menunjukkan bahwa intervensi DFT mampu menurunkan nilai OD IL-6 $(p=0,00)$ sebesar $22,82 \%$, namun belum mampu menurunkan kadar GDP dan nilai OD enzim COX-2 ( $p=0,22$ dan $p=0,51)$ secara statistik. DFT berpotensi dalam menurunkan senyawa pro-inflamasi IL-6 responden diabetes melitus tipe 2.
\end{abstract}

Kata kunci: diabetes melitus tipe 2, glukosa darah, inflamasi, tahu kedelai hitam

\section{PENDAHULUAN}

Diabetes melitus termasuk salah satu penyakit tidak menular utama yang jumlah penderitanya terus meningkat terutama di 131 negara-negara berkembang seperti Indonesia. WHO (2014) mengemukakan bahwa pada tahun 2012 diabetes 131 melitus telah menyebabkan kematian 1,5 juta jiwa di dunia

\footnotetext{
*Penulis Korespondensi:
}

E-mail: nelaeskaputri@gmail.com atau sekitar $4 \%$ dari total kematian yang disebabkan oleh penyakit tidak menular lainnya. Pada tahun 2015, total kematian akibat diabetes melitus menurut International Diabetes Federation (IDF) adalah sebanyak 5 juta jiwa. Jumlah penderita diabetes melitus berdasarkan data IDF 2015 adalah 415 juta orang dewasa dan 318 juta orang dewasa lainnya mengalami gangguan toleransi glukosa darah yang berpotensi dalam meningkatkan jumlah penderita diabetes. Indonesia sendiri menempati urutan 
ketujuh penderita diabetes melitus tertinggi di dunia dengan jumlah 10 juta jiwa pada tingkat umur 20-79 tahun. Penderita diabetes melitus tipe 2 mengalami gangguan sekresi insulin, yaitu sel beta pankreas tidak menghasilkan hormon insulin dalam jumlah yang cukup sehingga terjadi penumpukan glukosa di dalam darah, atau mengalami resistensi insulin, yaitu insulin tidak mampu menstimulasikan glukosa di dalam darah menuju sel karena reseptor insulin mengalami kerusakan. Hal ini menyebabkan terjadinya penumpukan glukosa di dalam darah. Kondisi ini disebut juga dengan hiperglikemik.

Hiperglikemik cenderung menimbulkan stres oksidatif yang memicu autooksidasi glukosa sehingga terbentuk oksigen radikal atau Reactive Oxygen Spesies (ROS) (Monroy dan Mejia, 2013). Autooksidasi glukosa terjadi pada proses glikasi nonenzimatik dengan protein yang menghasilkan hidrogen peroksida dan superoksida sebagai radikal bebas. Radikal bebas ini akan merusak DNA inti sehingga proses glikolisis terganggu dan menyebabkan munculnya jalur Advanced glycation end products (AGE) yang ditandai dengan meningkatnya $\mathrm{HbA}_{1 \mathrm{c}}$ pada darah. ROS juga merupakan salah satu pemicu timbulnya inflamasi atau peradangan.

Inflamasi dapat mengaktivasi pelepasan sitokin oleh sel dan jaringan tubuh, seperti IL-6 yang dilepaskan oleh makrofag (Hurst et al., 2001). Produksi sitokin oleh makrofag 132 bisa memberikan efek negatif terhadap sensitivitas insulin (Hussain et al., 2010). Pada penderita diabetes, inflamasi terjadi setelah terjadinya peningkatan glukosa darah yang ditandai dengan meningkatnya marker inflamasi seperti Interleukin. IL-6 merupakan salah satu penanda inflamasi yang berperan penting dalam patogenesis diabetes melitus. Single Nucleotida Pholimorphism (SNP)-G174C merupakan promotor gen pada IL-6 yang berasosiasi dengan T2DM, yang terkait juga dengan level dan resistensi insulin. IL-6 dapat menghambat auto-posporilasi reseptor insulin, menghambat transkripsi gen IRS, GLUT-4, dan PPAR-y, serta mengaktifkan degradasi IRS-1 dan IRS-2 di dalam proteasom (Nadeem et al., 2013). Selain itu, saat terjadi inflamasi maka sel-sel akan menginduksi enzim siklooksigenase (COX-2) dan enzim tersebut akan beredar di daerah tempat terjadinya inflamasi (Persaud et al., 2004). Hiperglikemik dapat meningkatkan sekresi insulin yang berlebihan oleh sel beta pankreas. Menurut Rachel et al. (2016), glukosa dapat menyebabkan meningkatnya ekspresi COX-2 yang dapat menurunkan bioavalibilitas nitrit oksida vasodilator dan kemunduran fungsi endotel pada penderita DM tipe 2.

Pengendalian glukosa darah dapat dilakukan dengan diet dan memodifikasi gaya hidup, seperti mengonsumsi makanan sehat, melakukan olahraga teratur dan tidak merokok. Makanan sehat yang dibutuhkan untuk mengontrol glukosa darah penderita diabetes melitus adalah makanan yang mengenyangkan, memiliki indeks glikemik rendah, kaya protein, serat dan antioksidan serta rendah kolesterol.

Kacang kedelai memiliki protein yang tinggi serta isoflavon yang berfungsi sebagai antioksidan. Menurut Muchtadi (2010), tahu merupakan bahan pangan yang diproduksi dengan cara mengendapkan susu kedelai menggunakan suatu koagulan. Koagulasi susu kedelai tersebut merupakan bentuk pengendapan protein, sehingga tahu memiliki protein yang tinggi. Tahu tidak mengandung pati dan memiliki indeks glikemik yang rendah serta membawa zat-zat gizi dan non-gizi seperti komponen bioaktif. Oleh karena itu tahu cocok untuk penderita diabetes. Menurut Nurrahman (2015), kedelai hitam memiliki protein yang hampir sama dengan kedelai kuning, selain itu kandungan antosianin sebagai antioksidan yang terdapat pada kulitnya menyebabkan kedelai hitam lebih unggul dibandingkan kedelai kuning, sehingga tahu kedelai hitam tentunya memiliki antioksidan yang juga lebih baik daripada tahu yang diolah dari kedelai kuning.

Pada proses pengolahan tahu kedelai hitam dihasilkan ampas kedelai yang kaya akan serat pangan, protein dan antioksidan. Pemberian tahu kedelai hitam yang diperkaya dengan serat (ampas kedelai) diharapkan dapat mengendalikan kadar glukosa darah serta menurunkan terjadinya inflamasi di dalam tubuh penderita diabetes melitus tipe 2. Penelitian ini bertujuan untuk melihat pengaruh intervensi tahu kedelai hitam kaya serat terhadap glukosa darah dan senyawa pro-inflamasi responden diabetes melitus tipe 2 .

\section{BAHAN DAN METODE}

\section{Bahan}

Bahan yang digunakan dalam penelitian ini adalah kedelai hitam varietas Detam 1 yang diperoleh dari Balai Penelitian Kacang-kacangan dan Umbi-umbian (Balitkabi) Malang, air, dan kalsium sulfat (sioko). Penelitian ini dilaksanakan pada bulan Oktober 2015 hingga Februari 2016 yang bertempat di Laboratorium Technopark dan Seafast Centre (produksi tahu), Klinik dr. Katili-Dramaga (sosialisasi program dan pengambilan darah responden), Laboratorium Analisis Biokimia ITP dan Laboratorium Biomedik FKH Institut Pertanian Bogor.

\section{Seleksi responden dan sosialisasi}

Penelitian ini dilakukan atas persetujuan dari Komisi Etika Penelitian Unika Atma Jaya melalui ethical clearance No: 1154/III/LPPM-PM.10.05/10/ 2015. Skrining awal adalah mencari calon responden diabetes melitus tipe 2 di sekitar Kampus IPB Dramaga. Kriteria responden adalah memiliki kadar 
glukosa darah puasa pada darah kapiler $\geq 126$ $\mathrm{mg} / \mathrm{dL}$ ataupun memiliki kadar glukosa darah sewaktu pada darah kapiler $\geq 200 \mathrm{mg} / \mathrm{dL}$, berusia 40 70 tahun, tidak menderita gangren dan penyakit kronis lainnya, dan pasien tidak dalam keadaan hamil. Penjajakan responden dilakukan dengan pemeriksaan glukosa darah gratis. Berdasarkan rumus Lameshow et al. (1997) dan hasil penelitian Chang et al. (2008) tentang kadar glukosa darah penderita diabetes melitus tipe 2 setelah suplementasi protein kedelai, maka jumlah responden (n) untuk penelitian ini dihitung berdasarkan rumus:

Keterangan:

$$
n=\frac{2(S)^{2}(Z \alpha+Z \beta)^{2}}{\left(X_{1}-X_{2}\right)^{2}}
$$

n : jumlah responden

S : standar deviasi $=42 \mathrm{mg} / \mathrm{dL}$ (Chang et al., 2008)

$\mathrm{Z \alpha}: 1,64(\alpha=5 \%)$

$Z \beta: 1,28(\beta=10 \%)$, power of test

$\mathrm{X}_{1}$ : mean kadar glukosa darah setelah intervensi $=110 \mathrm{mg} / \mathrm{dL}$ (Chang et al., 2008)

$\mathrm{X}_{2}$ : mean kadar glukosa darah sebelum intervensi $=170 \mathrm{mg} / \mathrm{dL}$ (Chang et al., 2008)

Berdasarkan rumus di atas diperoleh nilai $\mathrm{n}$ adalah 8,77 atau setara dengan 9. Selanjutnya responden dibagi menjadi 2 kelompok yaitu kelompok responden intervensi DFT (perlakuan) sebanyak 9 orang ( 4 orang laki-laki dan 5 orang perempuan) dan kelompok kontrol sebanyak 9 orang (4 orang laki-laki dan 5 perempuan).

\section{Pembuatan produk tahu kedelai hitam kaya serat (DFT) (Muchtadi, 2010 dengan modifikasi)}

Kedelai hitam disortasi untuk memperoleh biji kedelai yang baik dengan cara memisahkan biji dari kotoran serta memilih biji yang utuh. Selanjutnya dilakukan perendaman selama 12 jam dengan perbandingan berat biji kedelai dengan air adalah $1: 3(\mathrm{~b} / \mathrm{v})$. Setelah itu biji kedelai dibersihkan dan dicuci dengan perbandingan air 1:3 (b/v) sebanyak 3 kali sehingga diperoleh kedelai basah yang bersih. Kedelai yang sudah dicuci dihancurkan dengan menggunakan blender dengan perbandingan biji kedelai dan air adalah 1:8 (b/v). Bubur kedelai lalu disaring dengan saringan dan kain saring 60 mesh sehingga diperoleh susu kedelai (yang akan dimasak) serta ampas kedelai. Masing-masing filtrat maupun ampas ditimbang. Bubur kedelai mentah yang dihasilkan dididihkan selama 10 menit pada suhu $100^{\circ} \mathrm{C}$. Selanjutnya dilakukan penggumpalan (koagulasi). Koagulan yang dipakai adalah kalsium sulfat (Sioko) sebanyak $0,27 \%$ dari volume susu kedelai. Penggumpalan dilakukan pada suhu 70$75^{\circ} \mathrm{C}$, dimana terlebih dahulu dilakukan penambahan ampas kedelai (serat) sebanyak $2 \%(b / v)$ dari volume susu kedelai, lalu ditambahkan koagulan. Tahap selanjutnya adalah pemisahan cairan dan crude. Selanjutnya dilakukan pengepresan crude untuk membentuk tahu menggunakan alat pengepres pada skala pilot plant, dengan tekanan 2 $\mathrm{kg} / \mathrm{cm}^{2}$ selama 15 menit. Selanjutnya dilakukan pemotongan dan perebusan tahu.

\section{Intervensi produk}

Tahap intervensi merupakan tahap pemberian produk secara rutin ke rumah responden selama 30 hari kecuali kepada kelompok kontrol. Produk yang diberikan berupa tahu kedelai hitam kaya serat (DFT) dalam bentuk sup tahu yang diberikan setiap sore (pukul 16.00-17.00 WIB) kepada masingmasing responden. Jumlah DFT yang diberikan adalah sebanyak $\pm 80 \mathrm{~g}$ (mengandung 42,29\% protein bk dan $9,17 \%$ serat bk). Produk diantar menggunakan kemasan tupperware yang bisa digunakan kembali.

\section{Pengambilan darah}

Pengambilan darah dilakukan sebanyak dua kali yaitu pada tahap awal (pada hari ke-0, sebelum percobaan dimulai) dan pada akhir kegiatan (hari ke-30). Pada setiap tahap diambil darah vena. Darah diambil oleh tenaga medis yang berkompeten (di Klinik dr. Katili-Dramaga) sebanyak $8 \mathrm{~mL}$ dengan menggunakan syringe (Kendall Monoject $3 \mathrm{cc}$, USA) dan ditampung pada vacutainer (BD Vacutainer, USA) yang berisi antikoagulan EDTA.

\section{Analisis biokimia darah}

Analisis dilakukan pada plasma yang diperoleh melalui pemisahan darah responden sebelum dan sesudah intervensi. Darah yang diperoleh segera dibawa ke laboratorium untuk analisis IL-6 dan cOX-2.

\section{Analisis kadar glukosa darah puasa}

Kadar glukosa darah ditentukan menggunakan metode glucose oxidase sensor menggunakan glukometer (Accu-chek performa, Brasil). Darah diambil dari jari dengan cara jari dibersihkan dengan kapas beralkohol, lalu dipijat atau diurut perlahanlahan, kemudian bagian ujung jari ditusuk dengan jarum (lancet). Tetesan darah ditempelkan pada strip glukometer. Kadar glukosa darah akan terukur pada alat setelah 5 detik dan dinyatakan dalam satuan $\mathrm{mg} / \mathrm{dL}$, setelah itu dikonversikan menjadi $\mathrm{mmol} / \mathrm{L}$.

\section{Analisis kadar IL-6 dan COX-2 dengan metode Elisa (Zakaria et al., 2014 dengan modifikasi) \\ Sebanyak $100 \mu \mathrm{L}$ plasma darah diencerkan dengan bicarbonat buffer (Sigma Aldrich C3041, Singapore) (untuk IL-6=1:1.000; untuk COX- $2=1: 500$ ) dan dimasukkan ke dalam microplate 96}


well (NUNC 96 Maxisorp) kemudian diinkubasikan pada suhu $4^{\circ} \mathrm{C}$ selama semalam. Cairan di dalam well dibuang dan dicuci dengan larutan PBST $\mathrm{pH}$ 7,4 (larutan PBS: Sigma Aldrich P4417, USA; dengan 0,05\% Tween 20: Sigma Aldrich P1379, USA) sebanyak $250 \mu \mathrm{L}$ untuk setiap well selama 5 menit sebanyak tiga kali. Sebanyak $100 \mu \mathrm{L}$ susu skim (Sunnlac Low Fat) 5\% ditambahkan ke masingmasing well dan diinkubasikan pada suhu $37^{\circ} \mathrm{C}$ selama 1 jam. Setelah itu well dicuci lagi dengan larutan PBST $250 \mu \mathrm{L}$ selama 5 menit sebanyak tiga kali. Sebanyak $100 \mu \mathrm{l}$ antibodi primer (IL-6: Antibodi monoklonal anti IL-6 (Fitzgerald 10R-1787) = 1:8.000; COX-2: Antibodi monoklonal anti COX-2 (GeneTex GTX20701 = 1:600.000)) ditambahkan ke masing-masing well dan diinkubasikan pada suhu $37^{\circ} \mathrm{C}$ selama 1 jam. Setelah itu well dicuci lagi dengan larutan PBST $250 \mu \mathrm{L}$ selama 5 menit sebanyak tiga kali. Sebanyak $100 \mu \mathrm{L}$ antibodi sekunder HRP IgG anti-mouse (GeneTex GTX 26278) (1:10.000) ditambahkan ke masing-masing well dan diinkubasikan pada suhu $37^{\circ} \mathrm{C}$ selama 1 jam. Setelah itu well dicuci lagi dengan larutan 250 $\mathrm{ml}$ selama 5 menit sebanyak tiga kali. Dilakukan penambahan $50 \mu \mathrm{L}$ TMB (Sigma Aldrich T4444, USA) ke masing-masing well dan diinkubasikan di ruangan gelap selama 15 menit. Setelah diinkubasikan, ditambahkan larutan $\mathrm{H}_{2} \mathrm{SO}_{4} 50 \mathrm{~mL}$ (Sigma Aldrich, Singapore) ke masing-masing well lalu diukur absorbansinya dengan elisa reader (BIORAD Banchmark, Japan) pada panjang gelombang $450 \mathrm{~nm}$.

\section{Analisis statistik}

Analisis 134 statistik dilakukan dengan menggunakan uji $t$-student independent pada selang kepercayaan 95\% menggunakan SPSS Statistik 22 untuk melihat perbedaan data kadar GDP, IL-6, dan enzim COX-2 antara kelompok perlakuan dengan kelompok kontrol. Jika data tidak terdistribusi normal maka dilakukan uji non-parametrik Man-Whitney menggunakan SPSS Statistik 22.

\section{Analisis kadar air dengan metode oven, mengacu pada AOAC (1995)}

Kadar air diukur dengan metode oven biasa karena kandungan bahan volatil pada sampel rendah dan sampel tidak terdegradasi pada suhu $100^{\circ} \mathrm{C}$. Cawan aluminium kosong dikeringkan dalam oven bersuhu $105^{\circ} \mathrm{C}$ selama 15 menit lalu didinginkan dalam desikator selama 5 menit atau sampai tidak panas lagi. Cawan ditimbang dan dicatat beratnya. Lalu ditimbang sampel sebanyak $5 \mathrm{~g}$ di dalam cawan tersebut. Sampel dikeringkan dalam oven sampai beratnya konstan (perubahan berat tidak lebih dari $0,003 \mathrm{~g}$ ). Setelah itu cawan didinginkan di dalam desikator lalu ditimbang berat akhirnya. Dihitung kadar air dengan persamaan sebagai berikut:

$$
\operatorname{Kadar} \operatorname{Air}(\% \mathrm{~b} / \mathrm{b})=\frac{(\mathrm{x}-\mathrm{y}) \times 100 \%}{(\mathrm{x}-\mathrm{a})}
$$

Keterangan:

$\mathrm{x}$ : berat cawan dan sampel sebelum dikeringkan $(\mathrm{g})$

$\mathrm{y}$ : berat cawan dan sampel setelah dikeringkan $(\mathrm{g})$

a : berat cawan kosong $(\mathrm{g})$

\section{Analisis kadar abu dengan metode oven, mengacu pada AOAC (1995)}

Cawan porselen dibakar dalam tanur selama 15 menit kemudian didinginkan di dalam desikator (Duran, USA). Setelah dingin lalu cawan ditimbang. Kemudian sampel sebanyak $5 \mathrm{~g}$ ditimbang di dalam cawan tersebut lalu diabukan di dalam tanur hingga diperoleh abu berwarna putih dan beratnya tetap. Pengabuan dilakukan dalam dua tahap yaitu tahap pertama pada suhu $400^{\circ} \mathrm{C}$ lalu dilanjutkan pada suhu $550^{\circ} \mathrm{C}$, kemudian didinginkan di dalam eksikator lalu ditimbang. Kadar abu dihitung dengan rumus:

$$
\operatorname{Kadar} \text { Abu }(\% \mathrm{~b} / \mathrm{b})=\frac{\mathrm{W}_{1} \times 100 \%}{\mathrm{~W}}
$$

\section{Keterangan:}

W : berat sampel $(\mathrm{g})$

$\mathrm{W}_{1}$ : berat abu $(\mathrm{g})$

\section{Analisis kadar protein dengan metode kjeldahl, mengacu pada AOAC (1995)}

Sampel sebanyak 0,1-0,2 g dimasukkan ke dalam labu kjedahl (Sigma, Singapore) $100 \mathrm{~mL}$, lalu ditambahkan $2 \mathrm{~g} \mathrm{~K}_{2} \mathrm{SO}_{4}$ (Sigma Aldrich, Singapore), $40 \mathrm{mg} \mathrm{HgO}$ (Sigma Aldrich, Singapore), dan 2,5 mL $\mathrm{H}_{2} \mathrm{SO}_{4}$ pekat (Sigma Aldrich, Singapore). Setelah itu sampel didestruksi selama 30 menit sampai cairan berwarna jernih dan dibiarkan sampai dingin. Ditambahkan air suling secukupnya dan $10 \mathrm{~mL} \mathrm{NaOH}$ pekat (Sigma Aldrich, Singapore) ke dalam cairan sampai berwarna coklat kehitaman lalu didestilasi. Hasil destilasi ditampung dalam Erlenmeyer (Pyrex, Indonesia) $125 \mathrm{~mL}$ yang berisi $\mathrm{H}_{2} \mathrm{BO}_{3}$ (Sigma Aldrich, Singapore) dan indikator, kemudian dititrasi dengan $\mathrm{HCl}$ (Sigma Aldrich, Singapore) 0,02 N. Larutan blanko juga dianalisis seperti sampel. Kadar nitrogen dihitung berdasarkan rumus:

$$
\% \text { Nitrogen }=\frac{(\text { HCL-balnko) } \mathrm{mL} \times \mathrm{N} \mathrm{HCl} \times 14,007 \times 100 \%}{\mathrm{mg} \text { contoh }}
$$

Kadar Protein $(\%)=\%$ Nitrogen $\times 6,25$ 
Analisis kadar lemak dengan metode soxhlet, mengacu pada AOAC (1995)

Labu lemak yang telah bebas lemak dikeringkan di dalam oven kemudian ditimbang setelah didinginkan. Sampel sebanyak $5 \mathrm{~g}$ dibungkus dalam kertas saring kemudian ditutup dengan kapas yang bebas lemak. Sampel dimasukkan ke dalam alat ekstraksi soxhlet (Sigma, Singapore), kemudian dipasang kondensor dan labu pada ujung-ujungnya. Pelarut heksana dimasukkan ke dalam alat lalu sampel direfluks selama 5 jam. Setelah itu, pelarut didestilasi dan ditampung pada wadah lain. Labu lemak dikeringkan di dalam oven pada suhu $105^{\circ} \mathrm{C}$ sampai diperoleh berat tetap. Kemudian labu lemak dipindahkan ke desikator, didinginkan, dan ditimbang.

Keterangan:

$$
\text { Kadar Lemak }(\% \mathrm{~b} / \mathrm{b})=\frac{\mathrm{W}_{1} \times 100 \%}{\mathrm{~W}}
$$

W : berat sampel $(\mathrm{g})$

$\mathrm{W}_{1}$ : berat lemak $(\mathrm{g})$

\section{Analisis kadar karbohidrat by difference, me- ngacu pada AOAC (1995)}

Pengukuran kadar karbohidrat menggunakan metode by difference dilakukan dengan rumus: Kadar karbohidrat $(\% \mathrm{~b} / \mathrm{b})=100 \%$ - (kadar air + kadar protein + kadar lemak + kadar abu).

\section{Serat larut dan serat tidak larut, mengacu pada} AOAC official method 991.43

Sampel sebanyak $0,5 \mathrm{~g}$ ditimbang lalu ditambahkan $40 \mathrm{~mL}$ MES-TRIS (Sigma, Singapore) (bufer $\mathrm{pH}$ 8,2) dan distirer sampai homogen. Larutan ditambah dengan $50 \mu \mathrm{L}$ enzim $\alpha$-amilase (Sigma, Singapore) lalu disimpan di penangas air pada suhu $95-100^{\circ} \mathrm{C}$ selama 35 menit. Larutan didinginkan sampai suhu $60^{\circ} \mathrm{C}$, lalu dinding wadah piala dibilas dengan $10 \mathrm{~mL}$ air. Larutan ditambah dengan $100 \mu \mathrm{L}$ enzim protease (Sigma, Singapore) dan diinkubasikan pada suhu $60^{\circ} \mathrm{C}$ selama 30 menit. Larutan lalu ditambah dengan $\mathrm{HCl} 0,561 \mathrm{~N}$ sampai mencapai $\mathrm{pH}$ 4,1-4,8 dan ditambahkan $200 \mu \mathrm{L}$ enzim amyloglukosidase (Sigma, Singapore), lalu diinkubasikan pada suhu $60^{\circ} \mathrm{C}$ selama 30 menit. Larutan lalu disaring dan dicuci dengan $10 \mathrm{~mL}$ air bersuhu $70^{\circ} \mathrm{C}$ sebanyak dua kali, sehingga diperoleh filtrat dan air pencuci (A) serta residu (B). A dipindahkan ke dalam gelas piala dan ditambahkan etanol 95\% bersuhu $60^{\circ} \mathrm{C}$ sebanyak $4 \mathrm{x}$ volume larutan awal. Larutan diendapkan selama 1 jam lalu disaring. Setelah itu residu dikeringkan. Kadar serat larut diperoleh dari total residu dikurangi dengan kadar protein dan kadar abu. Sementara itu serat tak larut diperoleh dari total residu $\mathrm{B}$ dikurangi kadar protein dan kadar abu.
Serat total, mengacu pada AOAC official method 991.43

Sampel sebanyak $0,5 \mathrm{~g}$ ditimbang lalu ditambahkan $40 \mathrm{~mL}$ MES-TRIS (bufer $\mathrm{pH} 8$,2) dan distirer sampai homogen. Larutan ditambah dengan $50 \mu \mathrm{L}$ enzim $\alpha$-amilase lalu disimpan di penangas air pada suhu $95-100^{\circ} \mathrm{C}$ selama 35 menit. Larutan didinginkan sampai suhu $60^{\circ} \mathrm{C}$, lalu dinding wadah piala dibilas dengan $10 \mathrm{~mL}$ air. Larutan ditambah dengan $100 \mu \mathrm{L}$ enzim protease dan diinkubasikan pada suhu $60^{\circ} \mathrm{C}$ selama 30 menit. Larutan ditambah dengan $\mathrm{HCl} 0,561 \mathrm{~N}$ sampai mencapai $\mathrm{pH} 4,5(4,1-$ 4,6) lalu ditambahkan $200 \mu \mathrm{L}$ enzim amyloglukosidase. Larutan selanjutnya diinkubasikan pada suhu $60^{\circ} \mathrm{C}$ selama 30 menit dan diendapkan dengan $225 \mathrm{~mL}$ etanol $95 \%$ bersuhu $60^{\circ} \mathrm{C}$, lalu dibiarkan mengendap selama 1 jam pada suhu kamar. Endapan lalu disaring dengan kertas saring tak berabu No. 42 yang telah diketahui bobotnya. Larutan selanjutnya dicuci dengan $15 \mathrm{~mL}$ etanol $78 \%, 15 \mathrm{~mL}$ etanol $95 \%$ dan $15 \mathrm{~mL}$ aseton sebanyak dua kali. Lalu dikeringkan pada oven vakum $70^{\circ} \mathrm{C}$ atau pada suhu $105^{\circ} \mathrm{C}$. Selanjutnya didapatkan residu. Total serat pangan dihitung dengan rumus:

$$
\text { Serat Pangan Total }=\frac{\text { bobot residu }-(\mathrm{g} \text { protein }+\mathrm{g} \text { abu }) \times 100 \%}{\mathrm{~g} \text { contoh }}
$$

Catatan: kadar protein dihitung sesuai dengan SNI 01-2891-1992 butir 7.1, kadar yang diperoleh dikonversi ke gram dengan mengalikan 6,25, sedangkan kadar abu dikerjakan sesuai dengan SNI 01-28911992 butir 6.1

\section{HASIL DAN PEMBAHASAN}

\section{Karakteristik bahan baku dan produk intervensi}

Kedelai hitam lokal yang digunakan dalam pembuatan tahu kedelai hitam kaya serat adalah varietas Detam 1 yang komposisinya dapat dilihat pada Tabel 1. Tahu kedelai hitam kaya serat memiliki kadar protein yang tinggi $(52,86 \%)$ serta serat total yang juga tinggi, yakni sebesar $11,46 \%$ dalam basis kering. Menurut BPOM (2011), pangan yang memiliki kadar protein $>35 \%$ disebut sebagai pangan berprotein tinggi, dan pangan yang memiliki serat sebanyak $>6 \mathrm{~g} / 100 \mathrm{~g}$ termasuk pada golongan pangan berserat tinggi. Tahu kedelai hitam yang ditambahkan dengan ampas kedelai memiliki kandungan serat yang tinggi, selanjutnya disebut sebagai tahu kedelai hitam kaya serat.

Menurut Setiawan dan Suhartono (2005), penderita diabetes tipe 2 membutuhkan diet dengan pangan berserat tinggi serta memiliki antioksidan untuk menghambat kerusakan oksidatif di dalam tubuh. Menurut Ascencio et al. (2004), mengonsumsi protein kedelai dapat memperbaiki kadar lemak darah dan mengatur insulin dalam keadaan 
normal. Wardani dan Wardani (2014) menambahkan bahwa kedelai hitam berpotensi sebagai bahan baku minuman fungsional karena memiliki asam amino esensial, vitamin $E$, saponin dan kaya akan antioksidan misalnya flavonoid, isoflavon dan antosianin.

Tabel 1. Kandungan metabolit primer bahan baku kedelai hitam varietas Detam 1 dan produk DFT

\begin{tabular}{|c|c|c|c|c|}
\hline \multirow{2}{*}{ Parameter } & \multicolumn{2}{|c|}{ Kedelai Hitam } & \multicolumn{2}{|c|}{ DFT } \\
\hline & $\mathrm{bb}$ & bk & $\mathrm{bb}$ & bk \\
\hline $\begin{array}{l}\text { Rendemen } \\
\text { (g/100 g kedelai) }\end{array}$ & & & 210 & 43,66 \\
\hline Kadar air (\%) & 9,78 & 10,84 & 78,17 & \\
\hline Kadar abu (\%) & 5,24 & 5,81 & 1,56 & 7,15 \\
\hline Protein (\%) & 32,93 & 36,50 & 11,54 & 52,86 \\
\hline Lemak (\%) & 13,16 & 14,59 & 0,79 & 3,62 \\
\hline $\begin{array}{l}\text { Karbohidrat } \\
\text { (by different) (\%) }\end{array}$ & 38,89 & 43,11 & 7,96 & 36,46 \\
\hline $\begin{array}{l}\text { Serat larut } \\
(\mathrm{SDF})(\%)\end{array}$ & $\mathrm{Td}$. & $\mathrm{Td}$. & Td. & 5,04 \\
\hline $\begin{array}{l}\text { Serat tak larut } \\
\text { (IDF) (\%) }\end{array}$ & Td. & Td. & Td. & 6,42 \\
\hline $\begin{array}{l}\text { Kadar serat total } \\
\text { (TDF) (\%) }\end{array}$ & Td. & Td. & Td. & 11,46 \\
\hline
\end{tabular}

\section{Pengaruh terhadap glukosa darah puasa (GDP)}

Menurut ADA 2014 diabetes melitus ditandai dengan kandungan glukosa darah yang tinggi saat puasa, yaitu $\geq 7 \mathrm{mmol} / \mathrm{L}$ atau setara dengan $\geq 126$ $\mathrm{mg} / \mathrm{dL}$. Pada penelitian ini responden yang biasa mengonsumsi obat antidiabetes tidak disarankan untuk menghentikan pengobatannya. Pada Tabel 2 terlihat bahwa rata-rata responden memiliki kadar GDP yang tinggi pada hari ke-0, yaitu $9,90 \pm 3,43$

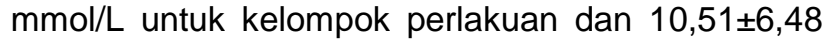
$\mathrm{mmol} / \mathrm{L}$ untuk kelompok kontrol. Berdasarkan hasil pengecekan rutin terlihat bahwa kelompok responden yang mengonsumsi DFT mengalami penurunan kadar GDP setiap minggunya (Gambar 1), sedangkan pada responden kontrol kadar glukosa darahnya mengalami penurunan yang tidak teratur (Gambar 2). Namun, intervensi DFT kepada 9 orang responden diabetes melitus tipe 2 selama 30 hari belum mampu menurunkan kadar GDP responden secara statistik.

Penderita diabetes melitus tipe 2 membutuhkan diet dengan pangan berprotein dan berserat tinggi yang dapat menekan rasa lapar. DFT merupakan produk pangan yang memiliki protein dan serat yang tinggi, selain itu juga memiliki pati yang yang rendah sehingga tidak cepat menaikkan glukosa darah. Menurut Santoso (2011) serat pangan mampu mengikat air dan glukosa sehingga daya cerna glukosa berkurang dan menurunkan kadar glukosa di dalam darah. Thondre (2013) juga mengemukakan bahwa serat dapat menurunkan glukosa darah karena memperlambat penyerapan glukosa postprandial dan waktu pengosongan lambung. Serat yang terdapat dalam DFT terdiri dari serat larut dan serat tidak larut. Menurut Takano et al. (2013), serat tidak larut dapat menekan kenaikan glukosa postprandial pada tikus dengan meningkatkan viskositas makanan di saluran cerna. Menurut Lu et al. (2013), serat larut berfungsi memperlambat pengosongan lambung sehingga memperlambat pencernaan dan penyerapan glukosa. Lebih jauh menurut Maulida et al. (2014) polisakarida larut air dapat menurunkan resistensi insulin dan mengurangi stres pada retikulum endoplasma pada tikus.

Tabel 2. Nilai rata-rata kadar glukosa darah puasa $(\mathrm{mmol} / \mathrm{L}) \pm \mathrm{SD}$ setelah intervensi DFT (hari ke-30)

\begin{tabular}{lccc}
\hline & Perlakuan & Kontrol & p-value \\
\hline $\begin{array}{l}\text { GDP }(m m o l / L) \\
\begin{array}{l}\text { Sebelum } \\
\text { (hari ke-0) }\end{array}\end{array}$ & $9,90 \pm 3,43$ & $10,51 \pm 6,48$ & $0,91^{*}$ \\
$\begin{array}{l}\text { Sesudah } \\
\text { (hari ke-30) }\end{array}$ & $7,69 \pm 1,41$ & $10,52 \pm 6,46$ & $0,22^{*}$ \\
$\begin{array}{l}\text { Perubahan }(\Delta) \\
\text { \% Perubahan }\end{array}$ & $-2,21$ & 0,01 & \\
\hline
\end{tabular}

Keterangan: Nilai $P>0,05$ adalah tidak berbeda nyata berdasarkan uji t-student independent. Tanda (-) artinya terjadi penurunan. *uji nonparametrik Man-Whitney

Penelitian preklinis Handayani et al. (2009) mengemukakan bahwa pemberian susu kedelai dapat menurunkan kadar glukosa darah postprandial tikus jantan secara signifikan, dimana polisakarida dan asam lemak omega-3 pada kedelai berperan dalam mengatur homeostatis glukosa darah. Menurut Ebrahimi et al. (2015), asam lemak omega-3 dapat meningkatkan regulasi PPAR-y yang dapat meningkatkan ekspresi gen yang mengkode GLUT-4 (tempat masuknya glukosa ke dalam sel).

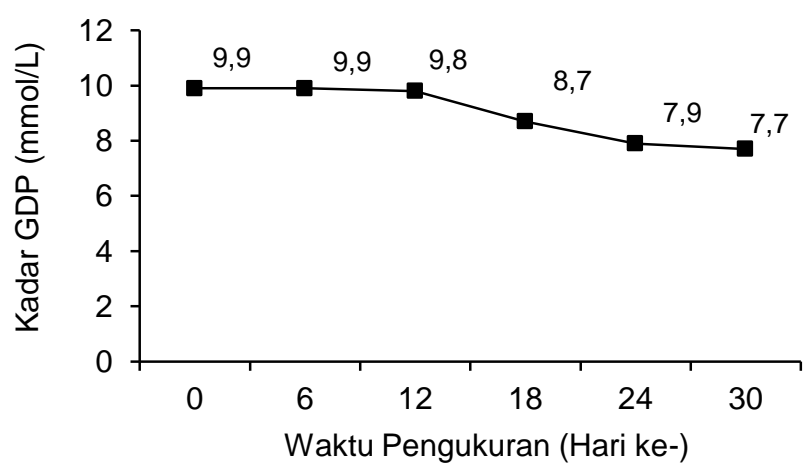

Gambar 1. Kadar glukosa darah puasa kelompok perlakuan selama 30 hari 
Selain protein, serat dan asam lemak esensial, lesitin kedelai juga berfungsi menurunkan kadar glukosa darah. Menurut Cahyono (2011), kandungan lesitin kedelai bertindak sebagai antioksidan yang mampu melindungi dan meregenerasi sel beta pankreas yang mengalami kerusakan, sehingga dapat menghasilkan insulin kembali. Dengan demikian glukosa darah dapat distimulasikan ke dalam sel. Selain itu, Kurimoto et al. (2013) mengemukakan fungsi lain dari kandungan kedelai, yaitu diet ekstrak kulit biji kedelai yang mengandung antosianin dan prosianidin pada tikus diabetes dapat memperbaiki kondisi hiperglikemik dan sensitivitas insulin melalui aktivasi AMP-kinase.

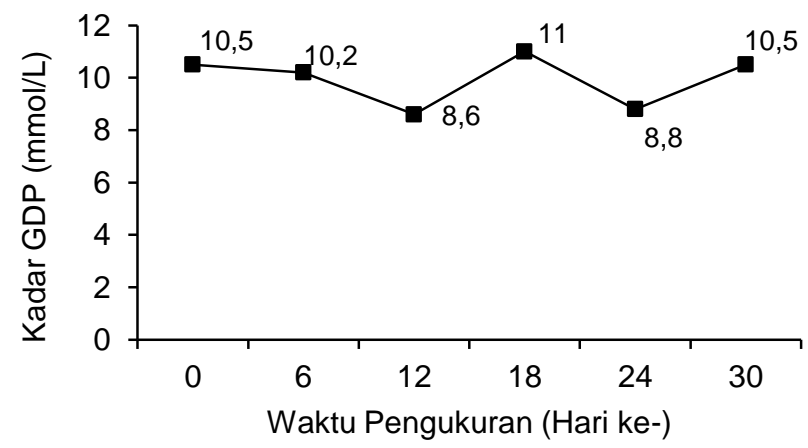

Gambar 2. Kadar glukosa darah puasa kelompok kontrol selama 30 hari

\section{Penurunan inflamasi}

Responden dalam penelitian ini mengalami kondisi hiperglikemik (Tabel 2). Kondisi hiperglikemik dapat menimbulkan terjadinya autooksidasi glukosa, sehingga menghasilkan oksigen radikal yang berlebih di dalam tubuh yang disebut juga dengan stres oksidatif. Menurut Monroy dan Mejia (2013) serta Zatalia dan Sanusi (2013), stres oksidatif dapat menimbulkan inflamasi atau peradangan yang juga berakibat pada resistensi insulin. Stres oksidatif berperan pada inflamasi sistemik, disfungsi endotel, gangguan sekresi sel beta pankreas dan gangguan utilisasi glukosa pada jaringan perifer. Menurut Hussain et al. (2010), inflamasi dapat menginduksi dikeluarkannya sitokin dari jaringan seperti IL-6, TNF- $\alpha$, dan leptin. Sitokin adiposit tersebut dapat menginduksi terjadinya resistensi insulin. Menurut Dandona et al. (2006), tingginya asupan makronutrisi dan glukosa ke dalam tubuh dapat menyebabkan stres oksidatif dan meningkatkan sitokin pro-inflamasi seperti IL-6 dan TNF- $\alpha$. Keberadaan IL- 6 dan TNF- $\alpha$ dapat mengganggu kerja insulin dengan cara menekan sinyal transduksi insulin.

Fungsi utama interleukin adalah sebagai respon imun awal yang dapat mengikat reseptor berafinitas tinggi pada permukaan sel (Febbraio, 2014). IL-6 terlibat dalam regulasi respon imun, fase akut, hematopoisis dan inflamasi. Sitokin IL-6 diproduksi oleh sel-sel endothel, fibroblast, monosit dan makrofag selama inflamasi (Akdis et al., 2011). Keadaan hiperglikemik pada penderita diabetes melitus dapat memicu terbentuknya radikal bebas yang juga dapat meningkatkan terjadinya inflamasi. Menurut Delichatsios dan Welty (2005), mengonsumsi makanan tinggi lemak jenuh dan glukosa dapat meningkatkan inflamasi dan adhesi molekul serta resistensi insulin.

Intervensi DFT belum mampu menurunkan kadar GDP responden DM tipe 2 (Tabel 2) namun dapat menurunkan inflamasi melalui penurunan nilai OD sitokin IL-6, yakni sebesar 22,27\% (Tabel 3). Penurunan ini lebih tinggi jika dibandingkan dengan kelompok kontrol $(p=0,00)$, dimana penurunan nilai OD IL-6 yang terjadi pada kelompok kontrol adalah sebesar $12,59 \%$. Penurunan sitokin IL-6 di dalam darah semua responden $(n=9)$ menandakan terjadinya pengurangan peradangan dan penurunan keparahan penyakit pada penderita diabetes melitus. Komposisi protein dan serat yang tinggi pada produk DFT dapat mencegah terjadinya autooksidasi glukosa dan mengurangi produksi radikal bebas di dalam tubuh. Selain itu, komponen bioaktif kedelai juga berperan sebagai antioksidan yang dapat menstabilkan radikal bebas sehingga menurunkan terjadinya peradangan atau inflamasi.

Tabel 3. Nilai optical density (OD) sitokin dan enzim pro-inflamasi \pm SD setelah intervensi DFT (hari ke-30)

\begin{tabular}{|c|c|c|c|}
\hline & Perlakuan & Kontrol & $\mathrm{p}$-value \\
\hline \multicolumn{4}{|l|}{ Sitokin IL-6 } \\
\hline $\begin{array}{l}\text { Sebelum } \\
\text { (hari ke-0) }\end{array}$ & $0,238 \pm 0,021$ & $0,366 \pm 0,056$ & 0,00 \\
\hline $\begin{array}{l}\text { Sesudah } \\
\text { (hari ke-30) }\end{array}$ & $0,185 \pm 0,014$ & $0,319 \pm 0,040$ & 0,00 \\
\hline Perubahan $(\Delta)$ & $-0,053$ & $-0,046$ & \\
\hline$\%$ Perubaha & 22,27 & 12,59 & \\
\hline \multicolumn{4}{|l|}{ Enzi } \\
\hline $\begin{array}{l}\text { Sebelum } \\
\text { (hari ke-0) }\end{array}$ & $0,180 \pm 0,023$ & $0,176 \pm 0,043$ & $0,31^{*}$ \\
\hline $\begin{array}{l}\text { Sesudah } \\
\text { (hari ke-30) }\end{array}$ & $0,170 \pm 0,021$ & $0,199 \pm 0,083$ & $0,51^{*}$ \\
\hline Perubahan ( & $-0,010$ & 0,024 & \\
\hline$\%$ Perubahan & 5,56 & 13,64 & \\
\hline
\end{tabular}

Keterangan: Nilai $P>0,05$ adalah tidak berbeda nyata berdasarkan uji t-student independent. Tanda (-) artinya terjadi penurunan. ${ }^{*} u j i$ non-parametrik ManWhitney

Penanda inflamasi selain IL-6 adalah diinduksinya enzim siklooksigenase (COX-2). Keadaan hiperglikemik dapat memicu dikeluarkannya enzim siklooksigenase (Persaud et al., 2004), selain itu enzim COX-2 juga diinduksi pada bagian tubuh yang luka sebagai respon terjadinya inflamasi (Gupta dan Yadav, 2011). Siklooksigenase akan berada pada 
jaringan yang mengalami inflamasi (Adelin et al., 2013). Sama halnya dengan IL-6, penurunan nilai OD enzim COX-2 sebagai penanda inflamasi terjadi setelah mengonsumsi DFT pada kelompok perlakuan $(\Delta=5,56 \%)$. Sedangkan pada kelompok kontrol terjadi peningkatan produksi enzim COX-2 sebesar 13,64\% (Tabel 3). Namun secara statistik DFT tidak mampu menurunkan inflamasi pada penderita DM tipe 2 melalui jalur COX-2.

Penelitian Jeon et al. (2011) menyatakan bahwa ekstrak kulit biji kedelai yang kaya akan antosianin dapat menekan sekresi enzim siklooksigenase (COX-2) sebagai pro-inflamasi pada tikus. Selain itu kedelai memiliki komponen bioaktif seperti isoflavon yang termasuk dalam golongan flavonoid. Hasil penelitian Chahyadi et al. (2014) menyatakan bahwa kandungan flavonoid yang diekstraksi dari tanaman Boesenbergia pandurata Roxb memiliki aktivitas antioksidan dan antiinflamasi, yaitu dapat menekan ekspresi iNOS dan enzim COX-2 serta aktivasi NF-KB. Setiawan dan Suhartono (2005) menambahkan bahwa pangan yang memiliki antioksidan dapat menghambat kerusakan oksidatif di dalam tubuh penderita diabetes melitus tipe 2 .

\section{KESIMPULAN}

Intervensi tahu kedelai hitam kaya serat (DFT) mampu menurunkan nilai OD IL-6 $(\mathrm{p}=0,00)$ sebesar $22,82 \%$, namun belum mampu menurunkan kadar GDP dan nilai OD enzim COX-2 secara signifikan $(p=0,22$ dan $p=0,51)$. Walaupun mengonsumsi DFT tidak signifikan menurunkan kadar gula darah tetapi tetap bermanfaat bagi penderita diabetes terkait kemampuannya menurunkan resiko inflamasi dengan memperngaruhi level IL-6 tapi bukan melalui jalur Cox-2.

\section{DAFTAR PUSTAKA}

[ADA] American Diabetes Association. 2014. Standards of medical care in diabetes 2014. Diabetes Care 37: S14-S80. DOI: 10.2337/ dc14-S014.

Adelin T, Frengki, Aliza O. 2013. Penambatan molekuler kurkumin dan analognya pada enzim siklooksigenase-2. J Medika Vet 7: 30-34. DOI: 10.21157/j.med.vet..v7i1.2916.

Akdis M, Burgler S, Crameri R, Eiwegger T, Fujita $H$, Gomez E, Klunker S, Meyer N, O’Mahony L, Palomares O, Rhyner C, Quaked N, Schaffartzik A, Veen WVD, Zeller S, Zimmermann M, Akdis CA. 2011. Interleukins, from 1 to 37, and interferon-y: receptors, functions, and roles in diseases. J Allergy Clin Immun 127: 701-721. DOI: 10.1016/j.jaci.2010.11.050.

[AOAC] Association of Analitycal Communities. 1995. Official Methods of Analysis of the Association of Official Analytical Chemistry. 16th Ed., AOAC International, Washington, USA. Pages: 1141.

Ascencio C, Torres N, Isoard-Acosta F, GomezPerez FJ, Hernandez-Pando $R$, Tovar AR. 2004. Soy protein affects serum insulin and hepatic SREBP-1 mRNA and reduces fatty liver in rats. J Nutr 134: 522-529.

[BPOM] Badan Pengawas Obat dan Makanan Republik Indonesia. Pengawasan Klaim dalam Label dan Iklan Pangan Olahan. 2011. Jakarta. Nomor HK.03.1.23.12.11.09909 hal. 18.

Cahyono AD. 2011. Manfaat susu kedelai sebagai terapi penurun kadar glukosa darah pada klien diabetes mellitus (Study eksperimental di poli penyakit dalam RSUD Pare Kabupaten Kediri tahun 2010). J Akademi Keperawatan Pamenang 4: 28-37

Chahyadi A, Hartatia R, Wirasutisna KR, Elfahmi. 2014. Boesenbergia pandurata Roxb., an Indonesian medicinal plant: phytochemistry, biological activity, plant biotechnology. Proced Chem 13: 13-37. DOI: 10.1016/j.proche.2014. 12.003.

Chang JH, Kim MS, Lii SS. 2008. Effects of soybean supplementation on blood glucose, plasma lipid levels, and erythtrocyte antioxidant enzyme activity in type 2 diabetes mellitus patients. Nutr Res Practice 2: 152-157. DOI: 10.4162/nrp.20 08.2.3.152.

Dandona P, Ghanim H, Mohanty P, Chaudhuri A. 2006. The metabolic syndrome: Linking oxidative stress and inflammation to obesity, type 2 diabetes, and the syndrome. Drug Develop Res 67: 619-626. DOI: 10.1002/ddr.20137.

Delichatsios HK, Welty FK. 2005. Influence of the DASH diet and other low-fat, high carbohydrate diets on blood pressure. Curr Ather Report 7: 446-454. DOI: 10.1007/s11883-005-0061-X.

Ebrahimi M, Rajion MA, Meng GY, Farjam AS, Oskoueian E, Jafari S. 2015. Diet high in $\alpha$ linolenic acid up-regulate PPAR- $\alpha$ gene expression in the liver of goats. Electronic $\mathrm{J}$ Biotech 18: 210-214. DOI: 10.1016/j.ejbt.2015. 03.009.

Febbraio MA. 2014. Role of Interleukins in obesity: implications for metabolic disease. Trends Inendocrinol Metabolism 25: 312-319. DOI: 10. 1016/j.tem.2014.02.004.

Gupta V, Yadav SK. 2011. Cyclooxygenase-2: pathway form anti-inflammatory to anticancer drugs - a review. Int J Pharm Life Sci 2: 571582l. 
Handayani W, Rudijanto A, Indra MR. 2009. Soybeen milk reduce insulin resistant in Rattus norvegicus of type 2 model diabetes mellitus 139. J Kedokteran Brawijaya XXV: 60-66.

Hurst SM, Wilkinson TS, McLoughlin RM, Jones $S$, Horiuchi S, Yamamoto N. 2001. IL-6 and its soluble receptor orchestrate a temporal switch in the pattern of leukocyte recruitment SEEN during acute Inflammation. Immunity 14: 705714. DOI: 10.1016/S1074-7613(01)00151-0.

Hussain A, Hydrie MZI, Claussen B, Asghar S. 2010. Type 2 diabetes and obesity: a review of current trends. J Diabetol 2: 1-7.

[IDF] International Diabetes Federation. 2015. IDF Diabetes Atlas $7^{\text {th }}$ Edition. www.idf.org/diabetes atlas. [September 2015].

Jeon AJ, Lim TG, Jung SK, Lee EJ, Yeom MH, Park JS, Choung MG, Lee HJ, Lim Y, Lee KW. 2011. Black soybean (Glycine max cv. Heugmi) seed coat extract suppresses tpa or uvb-induced cox-2 expression by blocking mitogen activated protein kinases pathway in mouse skin epithelial cells. Food Sci Biotechnol 20: 17351741. DOI: 10.1007/s10068-011-0239-7.

Kurimoto $Y$, Shibayama $Y$, Inoue $S$, Soga $M$, Takikawa M, Ito C, Nanba F, Yoshida T, Yamashita Y, Ashida H, Tsuda T. 2013. Black soybean seed coat extract ameliorates hyperglycemia and insulin sensitivity via the activation of AMP-Activated protein kinase in diabetic mice. J Agr Food Chem 61: 5558-5564. DOI: $10.1021 / \mathrm{jf401190y.}$

Lameshow S, Hosmer Jr DW, Klar J, Lwanga SK. 1997. Adequacy of Sample Size in Health Studies. 36-40. John Wiley and Son Ltd., Chichester (UK).

Lu F, Liu Y, Li B. 2013. Okara dietary fiber and hypoglycemic effect of okara foods. Bio Carbo Dietary Fiber 2: 126-132. DOI: 10.1016/j.bcdf. 2013.10.002.

Maulida D, Estiasih T. 2014. Efek hipoglikemik polisakarida larut air umbi gadung (Dioscorea hispida) dan alginat: kajian pustaka. J Pangan Agroindustri 2:136-140.

Monroy MLLV, Mejia CF. 2013. Oxidative Stress in Diabetes Mellitus and the Role of Vitamins with Antioxidant Actions. 209-232. DOI: 10.5772/ 51788. Intech. Rijeka, Croatia. European Union.

Muchtadi D. 2010. Kedelai Komponen untuk Kesehatan. 39-49. Alfabeta: Bandung.

Nadeem A, Naveed AK, Hussain MM, Aslam M, Siddiqui A, Saeed SA. 2013. Variations in association of Interleukin 6 -G174C single nucleotide polymorphism with type 2 diabetes mellitus-a review. Int $\mathrm{J}$ Diabetes Dev C 33: 186-191. DOI: 10.1007/s13410-013-0147-x.

Nurrahman. 2015. Evaluasi komposisi zat gizi dan senyawa antioksidan kedelai hitam dan kedelai kuning. J Aplikasi Teknol Pangan 4: 89-93. DOI: 10.17728/jatp.v4i3.133.

Persaud SJ, Burns CJ, Belin VD, Jones PM. 2004. Glucose-induced regulation of cox-2 expression in human islets of langerhans. Diabetes 53: S190-S192.

Rachel C, Thomas O, Steven $\mathrm{H}$, Steve $\mathrm{EH}$, Jeffrey WS, Sarah LP. 2016. The $-765 \mathrm{G}>\mathrm{C}$ cyclooxygenase-2 promoter polymorphism is associated with type 2 diabetes mellitus, low high-density lipoprotein and manifest angina. J Diabetes Metab 7: 686. DOI: $10.4172 / 2155-6156.1000$ 686.

Santoso A. 2011. Serat pangan (dietary fiber) dan manfaatnya bagi kesehatan. Magistra 23: $35-$ 40.

Setiawan B, Suhartono E. 2005. Stres oksidatif dan peran antioksidan pada diabetes melitus. Majalah Kedokteran Indonesia 55: 86-90.

Takano A, Kamiya T, Tomozawa H, Ueno S, Tsubata M, Ikeguchi M, Takagaki K, Okushima A, Miyata Y, Tamaru S, Tanaka K, Takahashi T. 2013. Insoluble fiber in young barley leaf suppresses the increment of postprandial blood glucose level by increasing the digesta viscosity. Evid-Based Comp Alt 2013: 1-10. DOI: $10.1155 / 2013 / 137871$.

Thondre PS. 2013. Food base ingredients to modulate blood glucose. Adv Food Nutr Res 70: 181-227. DOI: 10.1016/B978-0-12-4165557.00005-9.

Wardani AK, Wardani IR. 2014. Eksplorasi potensi kedelai hitam untuk produksi minuman fungsional sebagai upaya meningkatkan kesehatan masyarakat. J Pangan Agroin 2: 58-67.

[WHO] World Health Organization. 2014. Global Status Report on Communicable Disease 2014. Attaining the Nine Global Noncommunicable Diseases Targets; A Shared Responsibility. Hal.28. WHO: Switzerland

Zakaria FR, Azni IN, Syamsir E, Amalia KM, Yamani C. 2014. Pengaruh konsumsi minuman beroksigen terhadap inflamasi dan kapasitas antioksidan penderita penyakit paru obstruktif kronik (PPOK). J Teknol Industri Pangan 25: 31-38. DOI: 10.6066/jtip.2014.25.1.31.

Zatalia SR, Sanusi H. 2013. The role of antioxidants in the pathophysiology, complications, and management of diabetes mellitus. Acta Medica Indonesiana 45: 141-147. 